\title{
Carbon Recycling for Reduction of Carbon Dioxide Emission from Iron-making Process
}

\author{
Yukitaka KATO \\ Research Laboratory for Nuclear Reactors, Tokyo Institute of Technology, 2-12-1-N1-22, Ookayama, Meguro-ku, Tokyo 152- \\ 8550 Japan. E-mail: yukitaka@nr.titech.ac.jp
}

(Received on July 8, 2009; accepted on October 20, 2009)

\begin{abstract}
A new energy transformation concept based on carbon recycling, called the Active Carbon Recycling Energy System, ACRES, is discussed. In this system, hydrocarbons are regenerated from carbon dioxide by using a heat source that does not emit carbon dioxide, allowing the hydrocarbons to be re-used cyclically as energy carrier media. The thermodynamic feasibility of ACRES is compared with that of a hydrogen energy system. Carbon monoxide has a higher energy density than hydrogen and is highly compatible with conventional chemical, steel, and high-temperature manufacturing processes. Thus, it is a suitable carbon medium for ACRES. A high-temperature gas type nuclear reactor is a good power source for ACRES. The combination of the nuclear reactor and ACRES with carbon monoxide is expected to form the basis of a new ironmaking process that has low carbon dioxide emissions.
\end{abstract}

KEY WORDS: energy; energy system; carbon recycling; carbon monoxide; hydrogen.

\section{Introduction}

Energy security is critical to the industrial and economic development of a society. Rapid changes and instability in the market prices of primary energy sources will lead to economic confusion in any age. This paper discusses the establishment of energy security from the standpoint of carbon recycling. Carbon is the most important energy medium for the manufacturing industry and in the daily life of a human being, making carbon security essential for a sustainable society. In Japan, the supply of fossil fuels depends almost entirely on imports. The enthalpy of imported fossil fuels is $82 \%\left(18.9 \times 10^{18} \mathrm{~J}\right)$ of the total enthalpy of primary fuels used in Japan. ${ }^{1)}$ Seventeen percent of fossil fuels are converted into plastics, while the rest is consumed solely for heat generation. Japan undertook the obligation of adhering to the Kyoto Protocol, which came into effect in 2005, and will therefore need to drastically reduce its carbon dioxide $\left(\mathrm{CO}_{2}\right)$ emissions. However, any limits imposed on $\mathrm{CO}_{2}$ emissions will directly restrict the use of carbon resources, which will, in turn, severely affect the manufacturing and service industries. The simultaneous establishment of carbon security and lower $\mathrm{CO}_{2}$ emissions is thus an important subject for the development of a modern society.

Here, a new energy system in which carbon is reused cyclically is discussed to reduce the emission of carbon dioxide into atmosphere from industrial processes. A carbon recycling system already exists in nature. In this paper, the concept of the Active Carbon Recycling Energy System, ACRES, is discussed. In ACRES, $\mathrm{CO}_{2}$ is converted artificially into hydrocarbons by using a primary energy source that has no $\mathrm{CO}_{2}$ emissions, allowing the hydrocarbons to be re-used cyclically as energy carrying media. ACRES recycles carbon and transforms energy without $\mathrm{CO}_{2}$ emission. Because ACRES is expected to solve the $\mathrm{CO}_{2}$ emission problem, the feasibility of ACRES is discussed thermodynamically.

\section{Proposal}

\subsection{Conventional Water Recycle Energy Systems and ACRES}

ACRES is compared with conventional recycle energy systems in this section. Conventional recycling energy systems based on water are depicted in Fig. 1. Figure 1(a) shows a conventional steam engine in which the water/ vapor phase change is used for energy conversion. Primary energy is used for the evaporation of water, and a phase change from steam to water provides the energy output. Figure 1(b) indicates a hydrogen system in which water is decomposed into hydrogen $\left(\mathrm{H}_{2}\right)$ and oxygen by an energy input, and the oxidation of $\mathrm{H}_{2}$ provides the energy output.

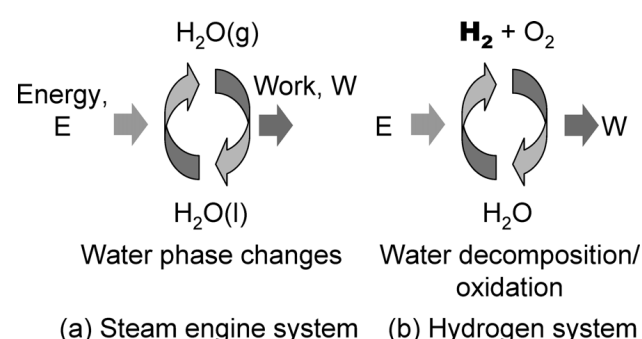

Fig. 1. Conventional water recycling energy systems. 


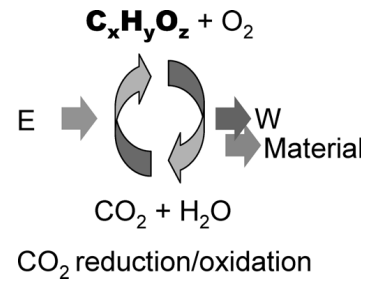

Fig. 2. Carbon recycling energy system.

The $\mathrm{H}_{2}$ energy system is superior to the vapor system at long-term energy storage with a small loss and a high energy density. However, $\mathrm{H}_{2}$ requires considerable work for compression up to 700 bars in storage, high-cost security for explosion prevention, and system complexity for energy conversion of the energy output as in fuel cells. These requirements are still a hindrance to the market development of a $\mathrm{H}_{2}$ energy system.

The proposed concept of ACRES is shown in Fig. 2. Carbon dioxide $\left(\mathrm{CO}_{2}\right)$ with/without water is the ground state of carbon. $\mathrm{CO}_{2}$ is converted into hydrocarbons or alcohols by an energy input using some catalytic technologies. ${ }^{2)}$ The produced hydrocarbons are useful for conventional manufacturing industry as thermal energy sources and row materials. These hydrocarbons provide thermal and electrical energies during the oxidation into $\mathrm{CO}_{2}$. The hydrocarbons can be used as raw materials for making industrial materials. These hydrocarbons are easy to be stored and can be transferred under a low compression pressure with a small explosion risk in comparison with $\mathrm{H}_{2}$. The hydrocarbons have a considerable potential for use in common manufacturing industries. If the carbon recycling system can be established thermally and kinetically, it is expected that the system is diffused easily into conventional industries. A natural carbon recycle energy system already exists in the plant kingdom and is an ideal recycling system. However, the potential amount of bio-mass recycled by this system is not sufficient to meet the demands of a modern society. In particular, the domestic bio-mass potential in Japan is less than $10 \%$ of the total domestic energy demand. ${ }^{3)}$ The natural recycling system is not sufficient to meet the energy demands in Japan. Therefore, an artificial active recycling system for carbon, viz., ACRES, is proposed in this study. The feasibility of ACRES is discussed from the viewpoint of enthalpy balances in this paper.

\subsection{Structure of ACRES}

The structure of ACRES shown in Fig. 3 consists of three elemental processes of hydrocarbon usage, $\mathrm{CO}_{2}$ recovery and separation, and hydrocarbon regeneration. In the usage process, hydrocarbons can be used as both a heat source and a material. $\mathrm{CO}_{2}$ generated from hydrocarbon consumption is recovered by physical and chemical sorptions. Recovered $\mathrm{CO}_{2}$ in a sorption material is separated thermally from the material by a heat input. This process produces highly concentrated $\mathrm{CO}_{2}$. Recovered $\mathrm{CO}_{2}$ is regenerated into hydrocarbons in the regeneration process. The regeneration process is endothermic and requires an energy input. In ACRES, the total energy input at recovery and separation $\left(E_{\mathrm{S}}\right)$, and regeneration $\left(E_{\mathrm{R}}\right)$ should be larger than the energy output of the usage process $\left(E_{\mathrm{U}}\right)$.

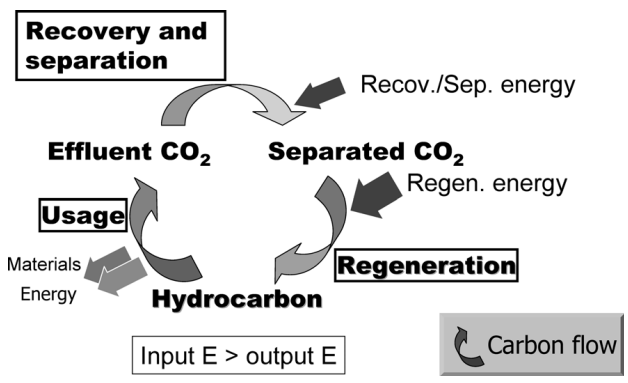

Fig. 3. Principle of ACRES with three elemental processes.

$$
E_{\mathrm{S}}+E_{\mathrm{R}}>E_{\mathrm{U}}
$$

ACRES is an energy consumption process; hence, a discussion of the energy balance of the system is required for the feasibility evaluation of the system.

\section{Enthalpy Evaluation of ACRES}

Practical hydrocarbons are examined those availability in ACRES by an enthalpy balance evaluation.

\subsection{Availability of ACRES with Methane}

Methane as a basic hydrocarbon is discussed first. In the usage process of methane, methane combustion (Eq. (2)) produces heat, methane steam reforming (Eq. (3)) produces hydrogen, and the polymerization of methane (Eq. (4)) produces polymeric materials.

$$
\begin{aligned}
& \mathrm{CH}_{4}+2 \mathrm{O}_{2} \rightarrow \mathrm{CO}_{2}+2 \mathrm{H}_{2} \mathrm{O}, \quad \Delta H=-802.3 \mathrm{~kJ} / \mathrm{mol} \ldots \text {. } \\
& \mathrm{CH}_{4}+2 \mathrm{H}_{2} \mathrm{O} \rightarrow \mathrm{CO}_{2}+4 \mathrm{H}_{2}, \quad \Delta H=+165.0 \mathrm{~kJ} / \mathrm{mol} \text {... } \\
& x \mathrm{CH}_{4} \rightarrow\left(-\mathrm{CH}_{2}-\right)_{x}+x / 2 \mathrm{H}_{2}
\end{aligned}
$$

$\mathrm{CO}_{2}$ is recoverable by physical adsorptions of active carbons or zeolites, or a chemical sorption by the carbonation of calcium oxide $(\mathrm{CaO})$ in the $\mathrm{CO}_{2}$ recovery and separation process. $\mathrm{CaO}$ can chemically absorb $\mathrm{CO}_{2}$ at temperatures of $500-800^{\circ} \mathrm{C}$ (Eq. (5)). $\mathrm{CaO}$ can remove $\mathrm{CO}_{2}$ from a hydrocarbon reaction system at the reaction temperature for $\mathrm{CO}_{2}$ production with a small sensible heat loss and enhance the reaction rate and yield of the $\mathrm{CO}_{2}$ production reaction. ${ }^{4)}$

$$
\mathrm{CaO}+\mathrm{CO}_{2} \rightarrow \mathrm{CaCO}_{3}, \quad \Delta H=-178.3 \mathrm{~kJ} / \mathrm{mol} \text {......(5) }
$$

In the process of methane regeneration from $\mathrm{CO}_{2}$, a twostep reaction of hydrogen production by water electrolysis and the methanation of $\mathrm{CO}_{2}$ with hydrogen (Eqs. (6) and (7)) is available.

$$
\begin{gathered}
\mathrm{H}_{2} \mathrm{O} \rightarrow \mathrm{H}_{2}+1 / 2 \mathrm{O}_{2}, \quad \Delta H=+241.8 \mathrm{~kJ} / \mathrm{mol} \ldots \ldots \ldots(6) \\
\mathrm{CO}_{2}+4 \mathrm{H}_{2} \rightarrow \mathrm{CH}_{4}+2 \mathrm{H}_{2} \mathrm{O}, \quad \Delta H=-165.0 \mathrm{~kJ} / \mathrm{mol} \ldots(7)
\end{gathered}
$$

The enthalpy balance of ACRES for methane is shown in Fig. 4. Because Eq. (7) needs $4 \mathrm{~mol}$ of $\mathrm{H}_{2}$, then fourfold large of $\Delta H$ of Eq. (6) is required for $\mathrm{H}_{2}$ production in the figure. Required enthalpies per one molecule of methane for the processes of usage and regeneration are depicted by the lower-heating value (LHV). Thermodynamic property values of reactions in the following were calculated on the basis of LHV because these reactions generally proceed at a sufficiently high temperature of more than $100^{\circ} \mathrm{C}$. The re- 


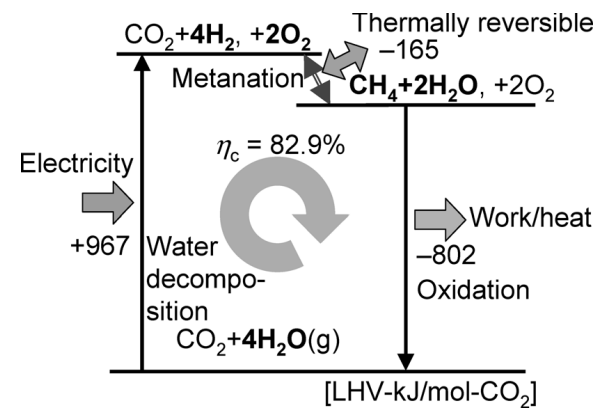

Fig. 4. Enthalpy balance of ACRES based on methane.

covery and separation process requires a relatively smaller enthalpy than one of other processes; further, it can be driven by waste heat at a relatively low temperature (less than $100^{\circ} \mathrm{C}$ ). Because the enthalpy evaluation for the recovery and separation process had uncertainties, the process was not taken into account in this system evaluation. The regeneration process assumed that hydrogen was used for hydrocarbon regeneration by the two-step reaction given in Eqs. (6) and (7). Production of $\mathrm{H}_{2}(4 \mathrm{~mol})$ needs an enthalpy of $967 \mathrm{~kJ} / \mathrm{mol}^{-\mathrm{CH}_{4}}$. The methanation of $\mathrm{CO}_{2}$ with $\mathrm{H}_{2}$ is an exothermic reaction of $165 \mathrm{~kJ} / \mathrm{mol}-\mathrm{CH}_{4}$. Regenerated methane has a reaction enthalpy of $802 \mathrm{~kJ} / \mathrm{mol}-\mathrm{CH}_{4}$. The circulation rate $\left(\eta_{\mathrm{c}}\right)$ which is the formation enthalpy ratio of the regenerated hydrocarbon to the required hydrogen is defined as follows:

$$
\eta_{\mathrm{c}}=\frac{\text { Formation enthalpy of regenerated hydrocarbon }}{\left(\begin{array}{r}
\text { Formation enthalpy of hydrogen of required } \\
\text { amount for hydrocarbon regeneration }
\end{array}\right)}
$$

$\eta_{\mathrm{c}}$ of methane for ACRES was $83 \%$. This means that an enthalpy loss is observed in the methanation process. However, when the same amount of enthalpy is stored in methane or $\mathrm{H}_{2}$, the methane storage pressure is reduced to one-third of the $\mathrm{H}_{2}$ storage pressure. Compression work can also be reduced to $1 / 3$ for methane storage in comparison with $\mathrm{H}_{2}$ storage. For comparison of energy efficiency between ACRES and the $\mathrm{H}_{2}$ system, a discussion considering comprehensive energy consumption in each system is needed. $\eta_{\mathrm{c}}$ of some hydrocarbons were calculated in Fig. 5. A higher $\eta_{\mathrm{c}}$ implies that enthalpy loss for the regeneration of the hydrocarbon becomes smaller. Methanol and ethanol are generally in liquid phase, easy to transport and store, and applicable to vehicles. Carbon monoxide (CO) has the highest $\eta_{\mathrm{c}}$ in the hydrocarbons.

\section{ACRES Based on CO}

\subsection{Enthalpy Analysis of ACRES Based on CO}

$\eta_{\mathrm{c}}$ of CO is $117 \%$. This shows that CO has a higher energy density than $\mathrm{H}_{2}$. $\mathrm{CO}$ is a popular energy material in conventional chemical, steel, and other manufacturing industries. Therefore, ACRES for $\mathrm{CO}$ is evaluated second. In the usage process of $\mathrm{CO}$, the oxidation of $\mathrm{CO}$ (Eq. (9)) for the heat output and the shift reaction of $\mathrm{CO}$ for $\mathrm{H}_{2}$ production (Eq. (10)) is available. CO can be also converted into polymeric materials by polymerization (Eq. (11)).

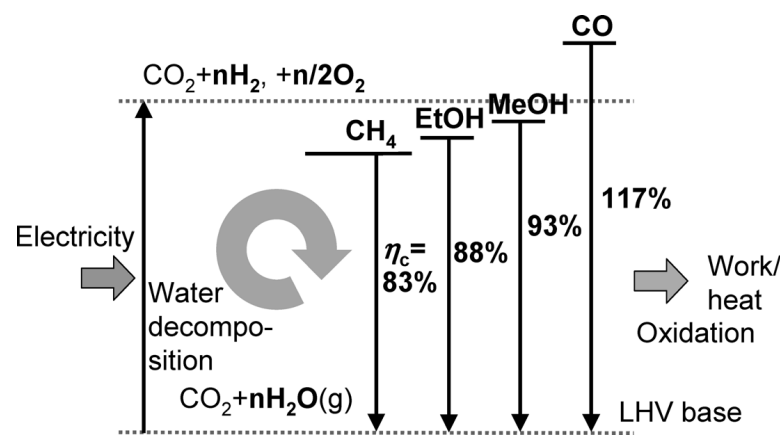

Fig. 5. Recycle ratios of ACRES based on some hydrocarbons using water electrolysis.

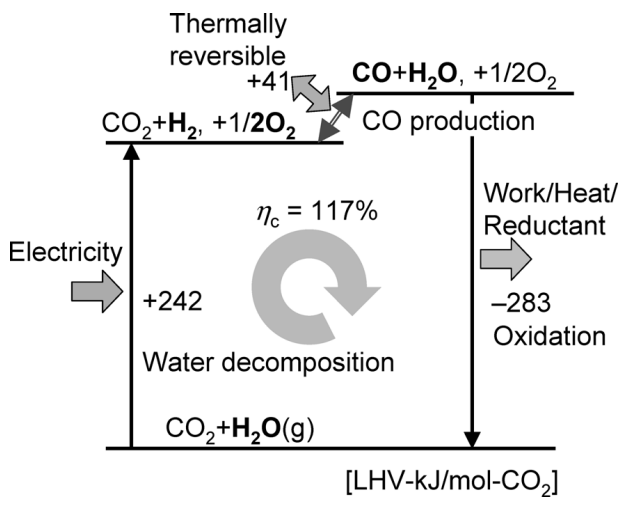

Fig. 6. Enthalpy balance of ACRES based on carbon monoxide.

$$
\begin{array}{r}
\mathrm{CO}+1 / 2 \mathrm{O}_{2} \rightarrow \mathrm{CO}_{2}, \quad \Delta H=-283.0 \mathrm{~kJ} / \mathrm{mol} \ldots \ldots . .(9) \\
\mathrm{CO}+\mathrm{H}_{2} \mathrm{O} \rightarrow \mathrm{H}_{2}+\mathrm{CO}_{2}, \quad \Delta H=+41.2 \mathrm{~kJ} / \mathrm{mol} \ldots . .(10) .(11) \\
x \mathrm{CO}+y \mathrm{H}_{2}+z \mathrm{O}_{2} \rightarrow \mathrm{C}_{x} \mathrm{H}_{2 y} \mathrm{O}_{(2 z+x)} \ldots \ldots \ldots \ldots \ldots . . . . . . . .
\end{array}
$$

$\mathrm{CO}$ is regenerative from $\mathrm{CO}_{2}$ by electrolysis (Eq. (12)).

$$
\mathrm{CO}_{2} \rightarrow \mathrm{CO}+1 / 2 \mathrm{O}_{2}, \Delta H=+283.0 \mathrm{~kJ} / \mathrm{mol}
$$

A two-step reaction of hydrogen production by water electrolysis and reduction of $\mathrm{CO}_{2}$ with the hydrogen (Eqs. (6) and (13)) is a practical process for CO regeneration.

$$
\mathrm{CO}_{2}+\mathrm{H}_{2} \rightarrow \mathrm{CO}+\mathrm{H}_{2} \mathrm{O}, \quad \Delta H=-41.2 \mathrm{~kJ} / \mathrm{mol} \text {. }
$$

The enthalpy balance of ACRES for CO is shown in Fig. 6. Required enthalpies per molecule of $\mathrm{CO}$ for the processes of usage and regeneration are shown in LHV. The regeneration process is assumed to use hydrogen for $\mathrm{CO}$ regeneration by the two-step reaction given in Eqs. (6) and (13).

Production of $\mathrm{H}_{2}(1 \mathrm{~mol})$ requires an enthalpy of $242 \mathrm{~kJ} / \mathrm{mol}-\mathrm{CO}$. Reduction of $\mathrm{CO}_{2}$ into $\mathrm{CO}$ with $\mathrm{H}_{2}$ is an endothermic reaction and requires a heat input of $41 \mathrm{~kJ} / \mathrm{mol}-\mathrm{CO}$. Because $\mathrm{CO}$ has a higher energy density than $\mathrm{H}_{2}, \mathrm{CO}$ is one of the most popular media in chemical processes.

$\mathrm{CO}$ is a considerably acceptable medium for conventional chemical and manufacturing industries. Hence, it is expected that $\mathrm{CO}$ is the most appropriate candidate for a regenerative medium in ACRES.

\subsection{Regeneration of $\mathrm{CO}$}

Efficient regeneration of $\mathrm{CO}$ is a key technology for ACRES based on CO. The feasibility of the regeneration 
methods of $\mathrm{CO}$ is evaluated.

\subsection{1. $\mathrm{CO}_{2}$ Hydrogenation}

The chemical reaction equilibrium for the $\mathrm{H}_{2} / \mathrm{CO}_{2} / \mathrm{CO} /$ $\mathrm{H}_{2} \mathrm{O}$ system of Eqs. (6) and (13) is shown in Fig. 7. It was assumed in the evaluation that the reaction proceeded under an equivalent ratio and a total pressure of $100 \mathrm{kPa} . \mathrm{CO}_{2} / \mathrm{CO}$ is reversible around $700^{\circ} \mathrm{C}$. This implies that the $\mathrm{CO}$ regeneration by $\mathrm{CO}_{2}$ hydrogenation in Fig. 6 requires a heat input of more than $700^{\circ} \mathrm{C}$. Because $\eta_{\mathrm{c}}$ of ACRES based on CO is $117 \%$, CO regeneration can recover all of the enthalpy of $\mathrm{H}_{2}$. Waste heat at a high temperature of around $700^{\circ} \mathrm{C}$ generated from the high-temperature processes can be utilized in the reaction. Energy saving of the high-temperature processes is achievable by which the waste heat generated from the processes is utilized for the regeneration process in the ACRES.

\subsection{2. $\mathrm{CO}_{2}$ Electrolysis}

$\mathrm{CO}_{2}$ electrolysis is one method of $\mathrm{CO}$ regeneration. Solid-oxide electrolysis cell (SOEC) in which a reverse operation of a solid-oxide fuel cell (SOFC) proceeds has a possibility for the electrolysis. ${ }^{5)}$ SOEC has been discussed for the production of a syngas, which is a mixture of $\mathrm{H}_{2}$ and $\mathrm{CO}$ generated from $\mathrm{H}_{2} \mathrm{O}$ and $\mathrm{CO}_{2}$. Temperature dependencies of enthalpy and Gibb's free energy changes, $\Delta H_{i}[\mathrm{~kJ} /$ $\mathrm{mol}]$ and $\Delta G_{i}[\mathrm{~kJ} / \mathrm{mol}]$, of Eq. (12) for the electrolysis of $\mathrm{CO}_{2}$ and Eq. (6) for $\mathrm{H}_{2} \mathrm{O}$ were calculated by a reaction equations module of HSC Chemistry (Ver. 6.12), Outotec. Electromotive forces, $V_{i}[\mathrm{~V}]$, for Eqs. (12) and (6) were derived from Eq. (14).

$$
V_{i}=\frac{-\Delta G_{i}}{n_{i} F}, \quad F=9.65 \times 10^{4} \mathrm{C} / \mathrm{mol}
$$

$n_{i}$ is the mole number of migrated electrons in a reaction. $\Delta G_{i}$ corresponds to the electrical energy for electrolysis. Electricity consumption ratio for electrolysis, $\eta_{\mathrm{el}-i}$, is defined as follows:

$$
\eta_{\mathrm{el}-i}=\Delta G_{i} / \Delta H_{\mathrm{i}}
$$

Both $V_{i}$ and $\eta_{\mathrm{el}-i}$ of Eqs. (12) and (6) are shown in Fig. 8. At higher temperatures, $\eta_{\mathrm{el}-\mathrm{CO}}$ and $\eta_{\mathrm{el}-\mathrm{H}_{2}}$ decreases. This implies that electrical energy consumption of $\mathrm{CO}_{2}$ electrol-

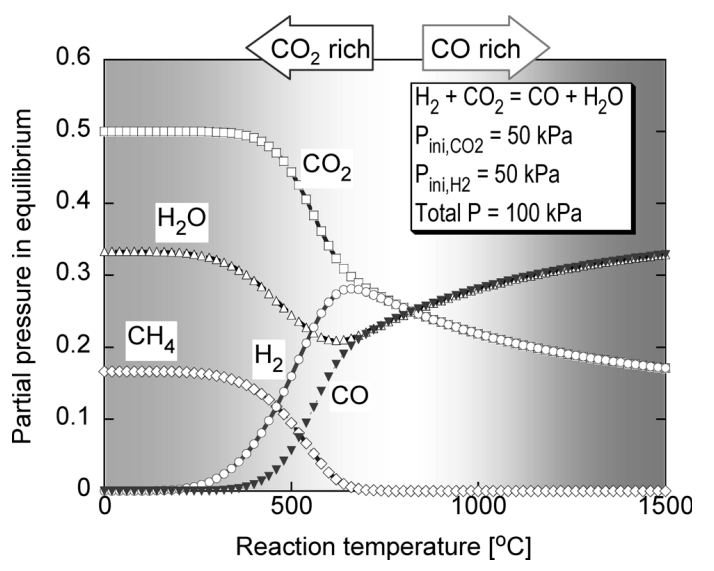

Fig. 7. Chemical reaction equilibrium for $\mathrm{H}_{2} / \mathrm{CO}_{2} / \mathrm{CO} / \mathrm{H}_{2} \mathrm{O}$ reaction system under $100 \mathrm{kPa}$. ysis becomes lower at a higher temperature like $\mathrm{H}_{2} \mathrm{O} . V_{\mathrm{CO}}$ becomes smaller than $V_{\mathrm{H}_{2}}$ at a temperature higher than $820^{\circ} \mathrm{C}$. This implies that higher-temperature $\mathrm{CO}_{2}$ electrolysis has a smaller demand for electrolysis than the $\mathrm{H}_{2} \mathrm{O}$ electrolysis.

\section{Application of ACRES}

The value of ACRES is that the system uses carbon cyclically and does not emit $\mathrm{CO}_{2}$ into atmosphere. The use of non-carbon primary energy sources is an essential requirement for a practical realization of ACRES. ACRES based on $\mathrm{CO}$ is the most effective recycling system in this evaluation. A high-temperature gas reactor type nuclear reactor (HTGR) is the most suitable energy source for ACRES because of the high-temperature output of up to $950^{\circ} \mathrm{C}$ with non-carbon emission and a sufficient amount of nuclear fuel to meet a country's demand. $\left.{ }^{6}\right)$ High-temperature electrolysis of $\mathrm{CO}_{2}$ using both heat and electricity outputs from HTGR is expected to have high efficiency than high-temperature electrolysis of water. The application of ACRES based on $\mathrm{CO}$ regenerated by high-temperature electrolysis driven by HTGR is proposed in Fig. 9. CO is used for the reduction of metal oxides or raw industrial materials (MO) into metals or reduced materials (M), and $\mathrm{CO}_{2}$ is generated from the reduction process. The generated $\mathrm{CO}_{2}$ is regenerated into $\mathrm{CO}$ during the high-temperature electrolysis using electricity and high-temperature (up to

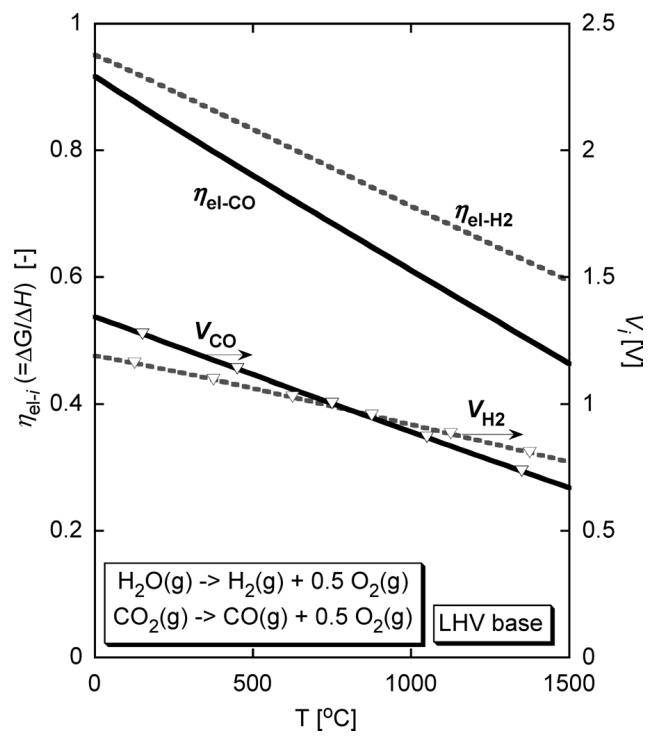

Fig. 8. Temperature dependencies of electricity consumption ratio for electrolysis and electromotive force for electrolyses of $\mathrm{CO}_{2}$ and $\mathrm{H}_{2} \mathrm{O}$ (LHV base).

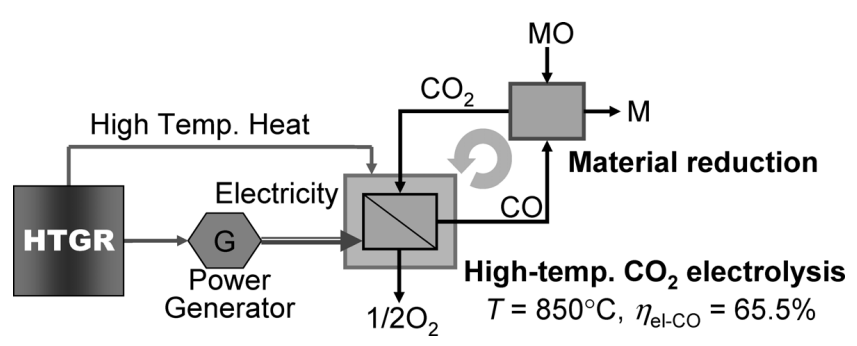

Fig. 9. ACRES with high-temperature $\mathrm{CO}_{2}$ electrolysis driven by HTGR. (MO: metal oxides or raw industrial materials, $\mathrm{M}$ : metals or reduced materials). 
$950^{\circ} \mathrm{C}$ ) heat. The electrolysis at $850^{\circ} \mathrm{C}$ has $\eta_{\text {el-CO }}$ of $65.5 \%$. The ratio at $25^{\circ} \mathrm{C}$ under atmospheric pressure is $90.9 \%$. Higher-temperature electrolysis can theoretically reduce $28 \%$ of the electricity consumption as compared to atmospheric electrolysis and has an advantage in terms of energy efficiency. The thermo-chemical reduction of $\mathrm{CO}_{2}$ is an ideal process for a reduction method like water decomposition because it does not consume any electricity. ACRES introducing a thermo-chemical $\mathrm{CO}_{2}$ decomposition process is shown in Fig. 10. High-temperature thermo-chemical $\mathrm{CO}_{2}$ decomposition has the highest energy efficiency. Thermo-chemical water decomposition into $\mathrm{H}_{2}$ requires multiple elemental reactions like the IS cycle. ${ }^{7)}$ A set of reactions for the thermo-chemical $\mathrm{CO}_{2}$ reduction needs to be found in future.

Application of ACRES to an iron-making process is proposed in Fig. 11. The application is based on the process shown in Fig. 9. The system is driven by electricity and thermal energy generated from HTGR. Regenerated CO is used for the reduction of iron monoxide into pure iron. $\mathrm{CO}_{2}$ generated from the reduction is regenerated into $\mathrm{CO}$ again by the $\mathrm{CO}_{2}$ decomposition process. Oxygen as the by-products of $\mathrm{CO}$ can be a useful material for other oxidation processes.

An iron-making process using hydrogen is discussed in a previous work. ${ }^{8}$ Iron(III) oxide (hematite), $\mathrm{Fe}_{2} \mathrm{O}_{3}$, is employed as a raw material for the process in the following discussion. $\mathrm{Fe}_{2} \mathrm{O}_{3}$ reduction by hydrogen is an endothermic reaction and requires an external heat input.

$$
\mathrm{Fe}_{2} \mathrm{O}_{3}+3 \mathrm{H}_{2} \rightarrow 2 \mathrm{Fe}+3 \mathrm{H}_{2} \mathrm{O}, \quad \Delta H=+104.9 \mathrm{~kJ} / \mathrm{mol} \text {. }
$$

In contrast, $\mathrm{Fe}_{2} \mathrm{O}_{3}$ reduction by $\mathrm{CO}$ is an exothermic reaction and proceeds spontaneously with self-heating.

$$
\mathrm{Fe}_{2} \mathrm{O}_{3}+3 \mathrm{CO} \rightarrow 2 \mathrm{Fe}+3 \mathrm{CO}_{2}, \quad \Delta H=-18.4 \mathrm{~kJ} / \mathrm{mol} \ldots .(17)
$$

$\mathrm{CO}$ reduction is advantageous for the iron-making process in comparison with hydrogen reduction. The reac-

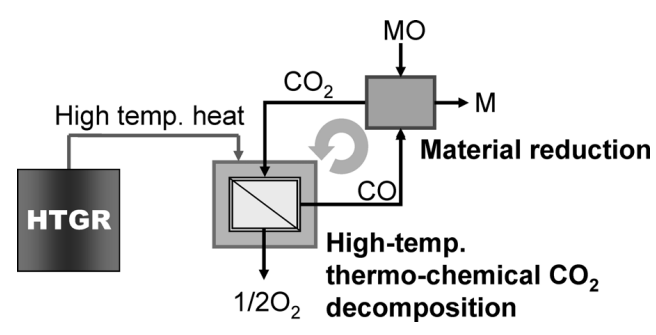

Fig. 10. ACRES with thermo-chemical $\mathrm{CO}_{2}$ decomposition driven by HTGR.

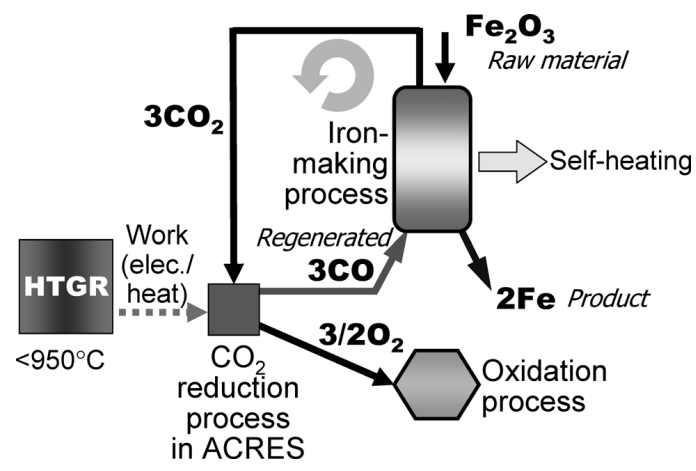

tion is usual in conventional iron making. Direct reduction processes for $\mathrm{Fe}_{2} \mathrm{O}_{3}$, in which $\mathrm{CO}$ and $\mathrm{H}_{2}$ gasses are used directly for the reduction, have been discussed. ${ }^{9}$ ACRES based on $\mathrm{CO}$ has a high affinity to such conventional processes. The iron-making process with ACRES is fundamentally a zero $\mathrm{CO}_{2}$ emission process. This process could be a possible way to reduce $\mathrm{CO}_{2}$ emission.

ACRES is an energy transformation system with energy consumption. The direct supply of a primary energy in an energy-demanding process without ACRES has the highest efficiency with the smallest energy loss. When a hydrocarbon recycled in ACRES is useful for energy demanding process compared with primary energies of heat or electricity, the ACRES is expected to have a practical value. In conventional chemical, steel, and other high-temperature manufacturing industries, $\mathrm{CO}$ has a higher affinity to processes than electricity and heat of primary energies. ACRES has the potential applicability in these industries as shown in Fig. 9. ACRES still requires efficient technologies for $\mathrm{CO}_{2}$ recovery and hydrocarbon regeneration. The development of a practical process using ACRES and the optimization of the process will be the focus of the next study.

\section{Conclusions}

For an establishment of a practical ACRES, appropriate selections of a recycling hydrocarbon medium and a primary energy source for the system drive were important. $\mathrm{CO}$ was the most suitable as the recycle medium in ACRES because $\mathrm{CO}$ had a higher energy density and affinity than $\mathrm{H}_{2}$ to chemical processes in conventional manufacturing industries. HTGR was a candidate of a primary energy source of ACRES. $\mathrm{CO}_{2}$ electrolysis at a high temperature had a higher efficiency than low temperature electrolysis. ACRES with $\mathrm{CO}$ driven by the heat output from HTGR was the most applicable combination. Application of ACRES to an iron-making process had the possibility to realize a zero $\mathrm{CO}_{2}$ emission process. ACRES was expected to be a candidate of energy systems for the establishment of carbon supply security in a modern society.

\section{REFERENCES}

1) Ministry of Economy: Energy Balance of Japan in 2004, The White Paper for Energy in 2006 FY, METI, Tokyo, Japan, (2006).

2) H. Kusama, K. Okabe, K. Sayama and H. Arakawa: Catal. Today, 28 (1996), 261.

3) H. Kameyama and Y. Kato ed., HONEBUTO Energy Road Map (Honebuto no Energy Road Map), Kagaku-Kogyo-Sha, Tokyo, Japan, (2005).

4) Y. Kato, K. Ando and Y. Yoshizawa: J. Chem. Eng. Japan, 36 (2003), 860.

5) S. H. Jensen, P. H. Larsen and M. Mogensen: Int. J. Hydrogen Energy, 32 (2007), 3253.

6) S. Fujikawa, H. Hayashi, T. Nakazawa, K. Kawasaki, T. Iyoku, S. Nakagawa and N. Sakaba: J. Nucl. Sci. Technol., 41 (2004), 1245.

7) A. Terada, J. Iwatsuki, S. Ishikura, H. Noguchi, S. Kubo, H. Okuda, S. Kasahara, N. Tanaka, H. Ota, K. Onuki and R. Hino: J. Nucl. Sci. Technol., 44 (2007), 477.

8) T. Murayama, S. Ishimatsu and K. Sawamura: Tetsu-to- Hagane, 63 (1977), 1090.

9) A. Bonalde, A. Henriquez and M. Manrique: ISIJ Int., 45 (2005), 1255 .

Fig. 11. ACRES for an iron-making process. 